\title{
Technological Innovation and Its Impact on Business Model, Organization and Corporate Culture - IBM's Transformation into a Globally Integrated, Service-Oriented Enterprise
}

\author{
Innovations in information and communication technology (ICT) are driving both globalization \\ and the change of value creation towards services. They are challenging companies to adapt \\ their business model, organization and corporate culture continuously and simultaneously \\ in order to stay competitive. An analysis of IBM's transformation over the past 50 years \\ reveals the opportunities and risks associated with ICT innovations and illustrates that \\ mastering professional change management will become a core issue for many companies.
}

DOI 10.1007/s12599-008-0002-7

\section{The Authors}

\author{
Martin Jetter \\ IBM Deutschland GmbH \\ Pascalstr. 100 \\ 70569 Stuttgart \\ Germany \\ http://www.ibm.de
}

\section{Prof. Dr. Gerhard Satzger \\ Andreas Neus \\ Universität Karlsruhe (TH) \\ Karlsruhe Service Research Institute \\ Englerstr. 11 \\ 76131 Karlsruhe \\ Germany \\ Gerhard.satzger@ksri. \\ uni-karlsruhe.de \\ http://www.ksri.uni-karlsruhe.de}

Received: 2008-05-16

Accepted: 208-07-31

Accepted after 2 revisions

by Prof. Dr. Buhl.

This article is also available in German in print and via http://www. wirtschaftsinformatik.de: Martin Jetter, Gerhard Satzger, Andreas Neus (2008) Technologische Innovation und die Auswirkung auf Geschäftsmodell, Organisation und Unternehmenskultur - Die Transformation der IBM zum global integrierten, dienstleistungsorientierten Unternehmen. WIRTSCHAFTSINFORMATIK. doi: 10.1007/s11576-008-0105-2.

\section{Introduction: information and communication technology as a driver of innovation}

In recent years the pace of innovation has risen dramatically, not least due to trailblazing developments in information and communication technology $(\mathrm{ICT})^{1}$. Fifteen years ago, electronic communication was still virtually unknown in business; today, business would be unimaginable without it. Every cellular phone, every MP3 player, and even some washing machines now have more computing capacity than the navigation computer that is still used to fly the Space Shuttle ${ }^{2}$. The availability of inexpensive mobile data storage has radically changed entire industries such as photography, media or telecommunications, as has the ubiquity of the Internet. Innovations - seen as novelties with a competitive effect ${ }^{3}$ - have the potential to

\footnotetext{
The convergence of nanotechnology, biotechnology, information technology and cognitive science (NBIC) is seen as the main driver in the years ahead (Bainbridge and Roco 2006, p. 5).

The Space Shuttle's avionics computers use IBM AP-101 family processors (originally ca. $400 \mathrm{~KB}$, and since $1991 \mathrm{ca} .1 \mathrm{MB}$ ) that were originally developed at the end of the 1960s (Tomayko 1988, p. 93). Due to the complexity of the safety-relevant system, NASA has hitherto chosen not to change the architecture. Embedded processors now used in the consumer goods sector are often more powerful in terms of sheer performance than these specialized chips (Schlett 1998, p. 49).

An innovation is generally understood to be a new idea, the market implementation of which is at least temporarily leading to a change in the competitive situation, giving the innovator a competitive edge (Hauschildt and Salomo 2007, pp. 46; Schumpeter 1983, p. 134 Cabral 1998, p. 818; Fagerberg 2004, p. 18).
}

revolutionize established markets practically overnight.

Even companies with a seemingly unassailable market position are under threat from the pace of innovation in the market. How fundamentally these often ICTdriven changes affect even large and dominant corporations is shown by the U.S. Standard \& Poor's 500 (S\&P 500) Index, which has been in existence since 1957. In 2007, 50 years after it was launched, only 86 of the original 500 companies are still listed in the index. In other words, fewer than 20 percent of the largest U.S. corporations have survived the past 50 years with their original relevance (Standard \& Poor's 2007). A large number of companies have disappeared, either taken over by more successful competitors or reduced to economic insignificance by failure to innovate in a core market. Many companies held on to established strategies and business models for too long - due either to inadequate strategic foresight or fear of cannibalization of their established business, to problems in implementing a new strategy, or to underestimating the speed at which innovations in, inter alia, ICT revolutionize entire market segments (Picot et al. 2008, p. 7). To hesitate in reacting to these changes, however, is to run a risk of being rolled over by market developments.

In the early 1990s, even IBM, one of the "survivors" of the initial S\&P 500 (Standard \& Poor's 2007) nearly fell victim to swift change in an ICT market that is relevant for the company in a twofold 


\begin{tabular}{|c|c|c|c|}
\hline Period & ICT Innovation & Direct Implication & Socio-economic Implication \\
\hline From $3100 \mathrm{BC}$ & $\begin{array}{l}\text { Development and } \\
\text { adoption of writing }\end{array}$ & $\begin{array}{l}\text { First-ever possibility for documentation } \\
\text { as separate from oral tradition }\end{array}$ & $\begin{array}{l}\text { Administration and growth of societies and } \\
\text { trade beyond the dimension of clans }\end{array}$ \\
\hline From 1450 & $\begin{array}{l}\text { The printing press with } \\
\text { movable metal types }\end{array}$ & $\begin{array}{l}\text { Reduction in the cost of } \\
\text { reproducing information }\end{array}$ & $\begin{array}{l}\text { Administration of large nation-states by standardized } \\
\text { distribution of information; standardization of language; } \\
\text { explosion in the amount of information available }\end{array}$ \\
\hline From 1850 & Telegraphy and the telephone & $\begin{array}{l}\text { Reduction in the time lost in } \\
\text { transporting information }\end{array}$ & Coordination of global trade \\
\hline From 1990 & $\begin{array}{l}\text { World Wide Web based } \\
\text { on Internet technology }\end{array}$ & $\begin{array}{l}\text { Separation of information from material } \\
\text { carriers and their economic limitations }\end{array}$ & $\begin{array}{l}\text { Global delivery of digital services; world- } \\
\text { encompassing added value networks }\end{array}$ \\
\hline
\end{tabular}

respect - as an innovation driver and as a core business area. Only by fundamentally changing its business model, organization and corporate culture was IBM able to surmount this crisis, and flexibility and the ability to change fast have since been the basis of its economic prosperity ${ }^{4}$.

In the following, first the influence of ICT on globalization and service-orientation is outlined (Chapter 2), followed by a consideration of the general relationship between business model, organization and corporate culture (Chapter 3 ). Then, the transformation at IBM in particular is analyzed. For three important phases during the past 50 years the market-driving innovations are identified and linked to the respective changes in business model, organization and corporate culture (Chapter 4). Finally, the results are summarized and an outlook is presented on the growing significance of transformation and change management (Chapter 5).

\section{The influence of ICT on globa- lization and service-orientation}

The influence of the swift pace of ICT developments is particularly evident in the increase in globalization and serviceorientation, also known as "servicization" (IfM, IBM 2008), that is particularly important for the transformation of many companies, including IBM.

\subsection{ICT and globalization}

Let us take a deliberately broad view of the term "information and communication technology" for a brief look back at the history of mankind, understanding it to

\footnotetext{
4 Rugman and Verbeke (2004) analyze "true global players" with a somewhat even distribution of business in America, Europe and Asia. They identify a company's ability to radically change as one of the characteristic properties that this requires.
}

mean all of the methods and techniques that relate to dealing with information. The last 5,000 years have witnessed four innovations that have led to such drastic changes in cost and speed in dealing with information that their effect not only on the markets but also on humankind as a whole can clearly be described as revolutionary (Tab. 1).

By the end of the nineteenth century, ICT had already been instrumental in initiating and implementing long-distance trade. In around 1990 the development of the World Wide Web marked a further milestone in stepping up the pace of globalization. Practically free worldwide transportation of data or information dramatically boosts the opportunities for international exchange of services. In contrast to trade in products, the globalization of which has reached new dimensions - a new quantity - in recent decades, trade in services has taken on an entirely new quality. The fast development of ICT has loosened the previous attachment of services to the place where they were provided. It took ICT and the Internet to make globalization of services, especially knowledge-intensive services, and corresponding global markets, conceivable and feasi$b^{5} e^{5}$. The globalization options for digital services are especially significant and are steadily gaining economic significance. New digital services (eServices), in particular Internet-based Web Services (Buhl et al. 2008, p. 63), account for a growing proportion of value added. Gartner (2008), for example, anticipates that by 2012 at least one third of application software in companies will be provided as "Software as a Service (SaaS)". These digital services can not only be traded over a network, but also

\footnotetext{
These internationalization opportunities are enhanced by the fact that in future markets such as India or China services account for only around 30 percent of gross value added and can still be expected to catch up in terms of service-orientation (Satzger 2008).
}

provided digitally in their totality, in other words delivered via private or public networks (typically the Internet) and thereby globally and independently of the place of provision. For many of the established industrialized nations this will present a major opportunity to countervail the future shifting of markets. While the gross domestic product of the so-called E7 states (the Emerging 7, consisting of Brazil, Russia, India, China, Indonesia, Mexico, and Turkey) at present amounts to a mere 20 percent of that of the G7 states, by 2050 the E7's gross domestic product is expected to have risen to around 125 percent of the corresponding $\mathrm{G} 7$ value ( $\mathrm{PwC}$ 2006, p. 18-23). The above-mentioned ICT enablement of international activities must be leveraged - also for developed countries like Germany - to participate in the growth of these markets.

\subsection{ICT and service-orientation}

In many developed economies services already account for over 70 percent of gross value added (Satzger 2008). The ongoing development of ICT will lead to a further increase in the share of services, due for one to a shift in scope of economic output from products to services and for another to the rising number of opportunities for de- and recomposition of added value networks and their coordination.

- Shift in scope of economic output: A widespread definition of services that goes back to Engelhardt et al. (1993, pp. 404 ff) and Meffert (1994, pp. $524 \mathrm{ff}$ ) describes them as a diffuse part of a performance continuum along the dimensions of intangibility and the inclusion of an external factor that again subdivides into the dimensions of the degrees of interaction and individualization. An economic output must be deemed increasingly as a service the more it consists of intan- 
gible components, the more interaction takes place with the customer in the provision of the output and the more individually the solutions are designed for the customer - so that the terminology established in practice, namely that of a "hard" distinction between products and services, can well be called into question (Satzger 1999, pp. 10-14; Vargo and Lusch 2004, pp. 5-12). Along all three dimensions ICT drives the significance of services. New, intangible services, such as Web Services, take shape or replace previous tangible ones. Opportunities for interaction and cooperation with the customer are intensified (via cooperation platforms, for instance). Opportunities for individualized production are increased by flexible production processes.

- De- and recomposition of added value networks: The focus on joint value creation also taken forward by the international initiatives promoting Service Science, Management and Engineering $(\mathrm{SSME})^{6}$, will increasingly lead to intensified endeavors to see services not only as the product of supply and demand but as added value cooperatively created by several partners (Spohrer and Kwan 2009). This can lead to longterm strategic partnerships, such as in IT outsourcing, or to short-term project-related organizational forms. In any case an increasing progression from established value chains to more complex, more dynamic, adaptive service value networks can be expected. A recent study by Deutsche Bank Research (2007, p. 8) names the change in business culture and value creation patterns as core dynamic processes for Germany's future development in addition to the design of the political and legal framework and to the exploitation of societal potential. ICT plays the role of an enabling coordination technology; uniform and/or open protocols and standards make a crosscompany creation of added value networks feasible. Service-oriented architecture concepts, not only applied on the ICT-infrastructural layer but also to business processes between com-

\footnotetext{
Cf. the initiatives of IBM (http://www-304.ibm. com/jct09002c/university/scholars/skills/ ssme/. Accessed 2008-08-15) or those of the international service research and innovation community (http://forums. thesrii.org/srii. Accessed 2008-08-15).
}

panies permit a greater specialization on the core competences of one's own company along with dynamic utilization of external added value components. The classic business question of whether to "make or buy" is to be reconsidered in many cases.

It should be noted that this ICT-driven service-orientation is further enhanced by two other observable trends:

- Societal developments promote the emergence of new services. The aging of society, for example, triggers additional demand for services in the healthcare or leisure area. The flexibility of individuals (in respect of forms of work, working times or length of service with one employer) lends further support to this trend.

- Promotion of political framework conditions (such as deregulation of markets and implementation of the EU Services Directive by the end of 2009) or systematic research funding in the services sector (such as promotion as a strategic area in the context of the German High-Tech Initiative (BMBF 2008)) eliminate barriers to growth.

- In the next section, the connection between innovations and the transformation of companies is first outlined in general terms before we proceed to specifically analyze the effect of ICT innovations on the transformation of IBM.

\section{The relationship between business model, organization and corporate culture}

Disruptive technological innovations regularly force companies and entire industries to adapt their business models and their organization (Christensen 1997, pp. 125-131; Picot et al. 2008, p. 7). Moreover, a dependency between business model, organizational structure and corporate culture has been postulated on a conceptual basis since the 1980s and investigated in greater detail in different models (such as by Wilkins and Ouchi (1983); Waterman et al. (1980)). Empirical analyses of the relation between corporate culture and success undertaken in subsequent studies produced partially inconsistent results. In later research it became clear that there is no such thing as a generally valid "best" corporate culture and that successful corporate cultures are evidently industry-specific and context- dependent (Christensen and Gordon 1999, p. 400; Baumöl 2006, pp. 315-316). Based on this hypothesis, significant changes in business models, such as the transformation from a product-oriented to a serviceoriented model, ought to be accompanied by no less radical changes in terms of a new corporate culture that supports the new model to the best possible degree. Adjusting a company's culture is a fundamental tasks of so-called change management (Kotter 1995, p. 64; Siegal et al. 1996, p. 57) and is considered to be an especially tough challenge: this was shown by the findings of a recent study by Jørgensen and Neus (2007, p. 87) in which 65 percent of project managers interviewed named "changing mindsets and attitudes" as the most serious obstacle to implementing change. It came well ahead of "scarcity of resources" (41 percent) and "lack of senior management commitment” (35 percent). Changing processes or IT systems, in contrast, cited by 20 and 8 percent of respondents respectively, are rated nowhere near as problematic (Fig. 1).

Successful companies typically develop strong corporate cultures that encourage and reinforce those attitudes to which the company owes its market success. The corporate culture thereby reflects the market situation (and the appropriate attitudes) in which the organization achieved success. If, however, the environment changes, due in this case to market changes, a strong corporate culture that has supported and strengthened previously valid success factors can turn into a problem because it hinders the adaptation of the organization and the development of new and different attitudes that are required for success in the new environment. A further factor that complicates matters is that often times parallel cultures coexist in companies, one being the official, documented and indeed believed culture stated in values and guidelines opposed to the actual culture that is lived in day-to-day business. Argyris and Schön (1978, pp. 12 ff) call this the difference between "espoused theory" and "theory in use."

In the following an analysis is undertaken of how the ICT-driven trends of globalization and service-orientation described in Sections 2.1 and 2.2 have made their mark on the development of IBM. We go into individual phases of the company's development and investigate on the basis of the ideas outlined in Section 3 not only the effects on business model and 


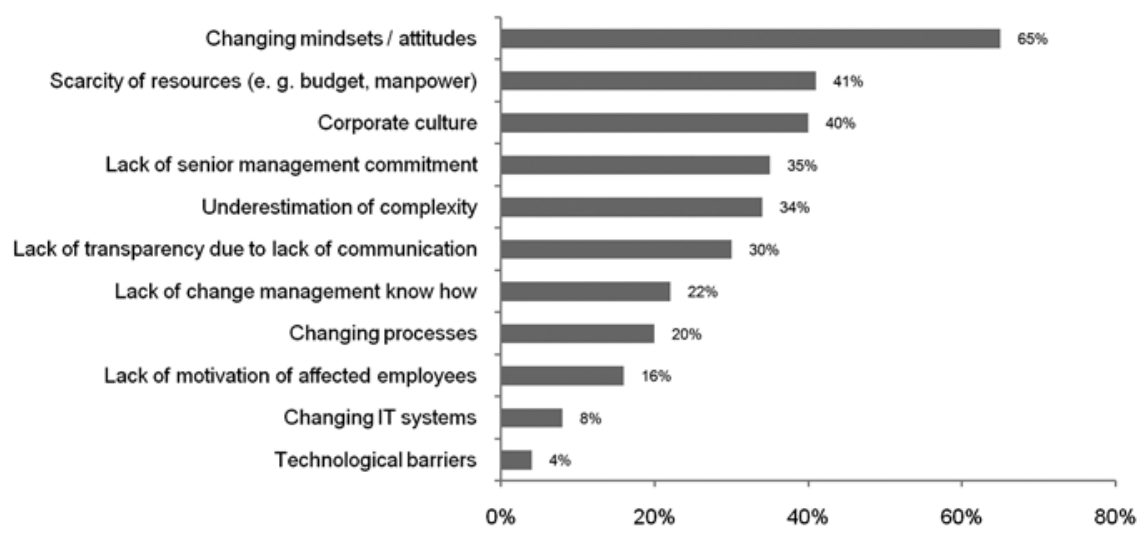

Fig. 1 Obstacles to the introduction of change based on interviews with 220 project and change managers in different industries in Germany, Austria and Switzerland (Jørgensen and Neus 2007, p. 87)
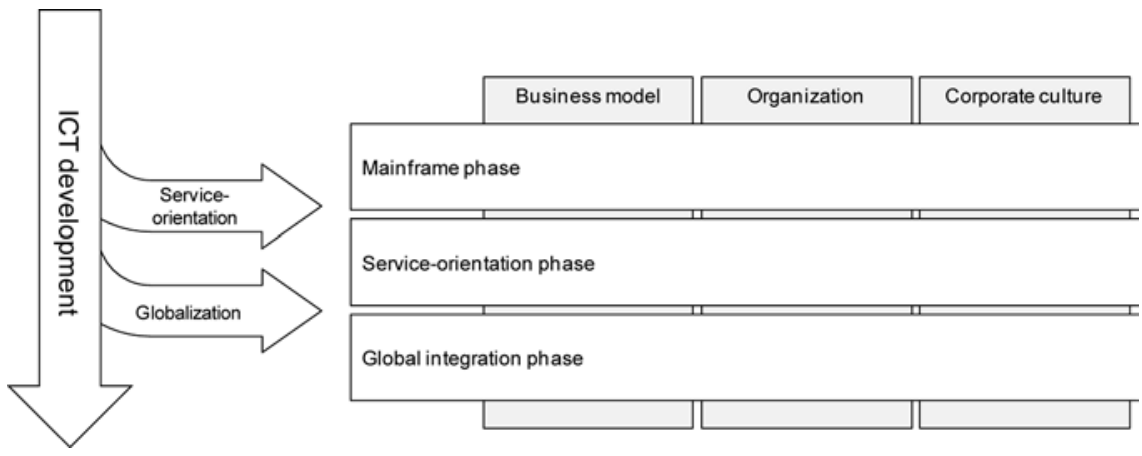

Fig. 2 Approach used to analyze IBM in chapter 4

organization but, especially, also on corporate culture. Fig. 2 provides an overview of the approach adopted.

\section{IBM: the past 50 years of transformation of business model, organization and corporate culture}

IBM is one of the few companies existing today with origins that date back to before 1900. Back in 1888, Herman Hollerith, a son of German immigrants, founded the Tabulating Machine Company (TMC) in New York to manufacture machines that automatically recorded and counted punchcards ${ }^{7}$. After mergers with other firms that produced, inter alia, scales and time recording devices, the Computing Tabulating Recording Company (CTR) was founded in 1911 and renamed International Business Machines in 1924.

DEHOMAG (Deutsche Hollerith-Maschinen Gesellschaft mbH), founded in Berlin in 1910, is considered to have been the forerunner of today's IBM Deutschland. Initially it was just a CTR licensee, however, it was taken over by CTR after economic difficulties in 1922.
From 1914 until a year before he died in 1956, Thomas J. Watson, Sr., headed the company and established an extraordinary culture that was characterized in particular by strong sales orientation and a sense of community among the company's employees. IBM has exercised a decisive influence on the development of ICT and at the same time undergone fundamental changes as a result of this development. The transformation of the past 50 years will be outlined in the following. For simplification, a distinction will be made between three major phase in which the development of ICT gave rise to different forms of business model, organization and corporate culture. Tab. 2 provides an overview of these phases, referred to in the following as the mainframe phase, the service-orientation phase, and the global integration phase.

\subsection{The mainframe phase}

In 1956, Thomas Watson, Jr., took over from his father as CEO. That was the period of the development and announcement of the System/360 mainframe family (in 1964) that marked a fundamental innovation in information technology and indirectly ushered in the development of disciplines such as informatics and, later, business and information systems engineering (BISE). What was so impressive about System/360 was the separation of architecture and product, leading to the emergence of a modular, scalable computer system that could be used for both scientific and commercial applications and combined the options of previously different and specialized computer architectures in a uniform architecture (IBM 1964) based on a modular system of integrated circuits with the aid of solid logic technology (Davis et al. 1964, pp. 102 ff). Basing System/360 on this new technology was a very risky strategic decision given the resources invested. At the time, Fortune magazine described the $\$ 5 \mathrm{~B}$ development costs as “IBM’s \$5B gamble" (Wise 1966, p. 118). The investment paid dividends, however. Instead of many voluminous special systems, customers were able for the first time to buy a generic computer that could grow with its task by means of modern add-on components without the software for a larger computer system needing to be rewritten each time. Subsequent technological innovations such as CMOS technology or RISC architecture further consolidated IBM's pioneering role.

IBM built its entire business model around the mainframes. The hardware, software, sales and services, the latter originally being merely system maintenance and not marketed separately, were all geared to System/360. Competitors had a tough time in view of IBM's research edge and its organization focused on this one system, and many providers vanished from the market. IBM long appeared to be unassailable until, on the one hand, the UNIX open operating environment in the early 1980s offered customers a realistic, high-performance non-proprietary alternative to IBM's mainframe products, while on the other the emergence of the personal computer, the market effect of which IBM initially underestimated, shifted the market towards decentralized concepts.

In the late 1980s, IBM's organization, which was originally focused entirely on System/360, was structured around different IBM product lines, each with its own head of sales. It soon transpired that an integrated view of the customers' problems was not available because the focus was on each unit's own solution. In later years, 


\begin{tabular}{|c|c|c|c|c|}
\hline \multirow[t]{2}{*}{ Phase } & \multirow{2}{*}{$\begin{array}{l}\text { ICT-based innovation as the starting } \\
\text { point }\end{array}$} & \multicolumn{3}{|l|}{ Implications for } \\
\hline & & Business model & Organization & Culture \\
\hline $\begin{array}{l}\text { "Mainframe" } \\
\text { (ca. 1956-90) }\end{array}$ & $\begin{array}{l}\text { Semiconductors, scalable computer } \\
\text { systems for business applications, } \\
\text { CMOS technology, RISC architecture }\end{array}$ & $\begin{array}{l}\text { Product provider of scalable } \\
\text { generic IT systems based } \\
\text { on outstanding research } \\
\text { and development }\end{array}$ & $\begin{array}{l}\text { Product-centered } \\
\text { marketing / sales silos }\end{array}$ & $\begin{array}{l}\text { Focus on research and devel- } \\
\text { opment, marketing and sales }\end{array}$ \\
\hline $\begin{array}{l}\text { "Service- } \\
\text { orientation" } \\
\text { (ca. 1990-2002) }\end{array}$ & $\begin{array}{l}\text { Open UNIX architecture, } \\
\text { personal computer, Internet }\end{array}$ & $\begin{array}{l}\text { Service-oriented integrator of IT } \\
\text { solutions from different provi- } \\
\text { ders to solve a client's problem }\end{array}$ & $\begin{array}{l}\text { Solution-centered } \\
\text { matrix: } \\
\text { 1. Solutions } \\
\text { 2. Industries }\end{array}$ & $\begin{array}{l}\text { Focus on integration and } \\
\text { market penetration }\end{array}$ \\
\hline $\begin{array}{l}\text { "Global } \\
\text { integration" } \\
\text { (since ca. 2002) }\end{array}$ & $\begin{array}{l}\text { Commoditization of IT products, } \\
\text { development of higher quality IT } \\
\text { services, open source networks, } \\
\text { Web 2.0 }\end{array}$ & $\begin{array}{l}\text { Provider of global services to } \\
\text { boost clients' innovation and } \\
\text { competitive capabilities }\end{array}$ & $\begin{array}{l}\text { Global customer- } \\
\text { centered matrix: } \\
\text { 1. Industries } \\
\text { 2. Solutions } \\
\text { Globally integrated } \\
\text { processes }\end{array}$ & $\begin{array}{l}\text { Focus on utilizing global com- } \\
\text { petences and on innovation } \\
\text { and added value for customers }\end{array}$ \\
\hline
\end{tabular}

this would even lead to internal competition between mainframe, AIX, AS/400 und PC business units offering customers solutions that sometimes overlapped and were positioned not only against the competition but also against other IBM solutions. While clearly not optimal, this was still bearable in an almost monopolistic market with a limited number of offerings - as IBM held a market share of up to 70 percent (Pugh 1995, pp. 57-58). In an increasingly competitive environment, though, with a large number of alternative products it was posing a serious risk.

In 1969, IBM's success even led to the U.S. Department of Justice filing a suit against it for establishing a monopoly position (and thereby breaching the 1890 Sherman Antitrust Act), ushering in years of litigation. The case was dropped in 1983, but it nevertheless had far-reaching effects on the company's business model and organization. In 1969, the previously uncustomary unbundling of software marketing software separately from hardware - was introduced. This has widely been regarded as the trigger for the establishment of today's software market (Grad 2002, p. 70; Pugh 2002, p. 58). By the same token, training services were offered for purchase to non-IBM customers for the first time. This marked IBM's initial step in the direction of a more comprehensive IT service offering. Organizationally, the antitrust suit led to IBM spending years preparing to split into two separate companies. This project was not further pursued, though, once the case was dropped.

The System/360 innovation also had consequences for IBM's corporate culture. Watson had deliberately and systematically institutionalized three "basic beliefs" that had made IBM successful under his leadership. They were "excellence in

\begin{tabular}{|c|c|}
\hline $\begin{array}{l}\text { Officially Proclaimed Value } \\
\text { (Espoused Theory) }\end{array}$ & $\begin{array}{l}\text { Value Actually 'Lived' After } 30 \text { Years } \\
\text { (Theory in Use) }\end{array}$ \\
\hline "Superior customer service" & "Perfect system maintenance" \\
\hline "Excellence in everything we do" & $\begin{array}{l}\text { "Perfection is more important than } \\
\text { speed or market acceptance" }\end{array}$ \\
\hline "Respect for the individual" & $\begin{array}{l}\text { "Every individual should support all decisions } \\
\text { but may, if need be, block them" }\end{array}$ \\
\hline
\end{tabular}

everything we do," "superior customer service" and "respect for the individual." These values were firmly incorporated in the remuneration and incentive systems, management training, other training programs, marketing, and customer service, and they enhanced each other. In around 1990, however, the importance and implications of these basic beliefs were entirely different from what they had been in 1960. Rules, values and traditions had not changed with the market and customer environment (Tab. 3):

- In the heyday of System/360, superior customer service mainly meant maintenance of machinery installed at the customer's premises. Over time, however, the service required became more complex and the customers' needs changed without IBM's offerings reflecting this change. Traditional customer service was more of a routine administrative task than a customized activity geared to each customer's requirements.

- Over a period of 30 years in which these values - also driven by the commercial success of the mainframe architecture - were manifested even more strongly in the corporate culture and in IBM's formal structures, a feeling of unassailability was at times widespread among IBM employees. As IBM's later CEO,
Lou Gerstner, wrote when looking back (Gerstner 2003, p. 189), they seemed to be immune to external influences such as competition, price wars and the like. All of the important developments in IT seemed to originate in IBM research laboratories. Viewed in this light, changes in customer requirements were not a central factor. Excellence in everything we do put the ability to adapt and the speed of change on the back burner. In 1972, for example, former IBM employees founded SAP because they saw no way within IBM to satisfy the growing customer demand for standardized, real-time financial applications.

- The interpretation of respect for the individual changed in much the same way. Given the extent of market success this belief was in some cases interpreted as meaning that every opinion within the company must be heard and "respected," leading to a lack of readiness to make decisions at IBM (Gerstner 2003, p. 192).

\subsection{The service-orientation phase}

Innovations in ICT such as the development of personal computers, the establishment of open standards and the concept of client-server architectures - for which 


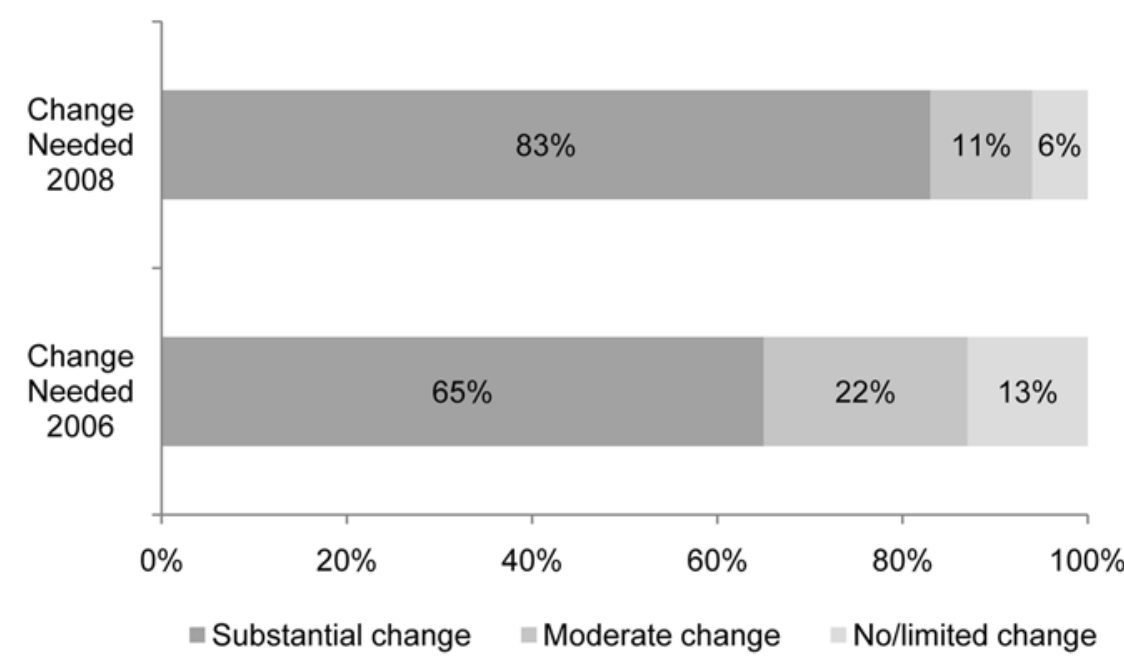

Fig. 3 Comparison of the 2006 and 2008 IBM CEO studies - 83 percent of respondents now expect to have to handle fundamental transformations in the near future (IBM 2008b, p. 7)

IBM was not sufficiently prepared ${ }^{8}$ - led to a progressive decline in the importance of mainframes. Financially, this was intensified by a drastic fall in prices due to the introduction of efficient CMOS technology with which IBM itself was largely associated. The medium-term result was the most serious crisis in the company's history. After two years with losses of more than $\$ 1 \mathrm{~B}$, IBM reported losses totaling $\$ 4.97 \mathrm{~B}$ for 1992 , at the time the largest-ever corporate loss in U.S. history (Burgess 1993, p. 3).

It was in this phase that Lou Gerstner took over as CEO in 1993. He realized that the key to restoring the company's profitability lay in the need to transform its business model. Anticipating that market growth would be mainly in the implementation of technologies, he transformed IBM's service business from an organization that dealt solely with IBM products (and mainly with their repair and maintenance) into a business unit focused on understanding and satisfying customers' needs. Whereas previously only IBM solutions were sold, competitors' services were now included - if they suited the customer's requirements - and the entire solution was integrated as a service and operated after the sale or developed further if required. At the end of 2002, the $\$ 3.5 B$ acquisition of PriceWaterhouseCoopers Consulting ( $\mathrm{PwCC}$ ), one of the largest

\footnotetext{
8 In the early 1980s, IBM bought in key components such as its operating system and microprocessor in order to gain momentum in its battle for the PC market with Apple. That helped Microsoft and Intel to gain their later predominant position in the IT industry.
}

professional services organizations with around 30,000 employees worldwide, was further evidence for this transformation. Experts saw in it an unexpected change in the market situation: Gartner analyst Ben Pring wrote that "IBM caught everyone unaware with a deal that, although not the largest in revenue terms, is one of the most significant in some time in terms of market dynamics" (Gartner 2002). At the same time IBM stepped up the expansion of its software business, realizing that it must seek to provide total solutions for the customer. This expansion began with the takeover of Lotus in 1995, and its focus was always on middleware as the key to designing integrated total solutions.

It had decisive consequences for the organization. The commitment to a compact IBM is considered one of Gerstner's most courageous decisions ${ }^{9}$. He did not pursue moves called for by the financial markets to break up the company into small, flexible units - in order to promote IBM's total solution competence and to make the change evident ${ }^{10}$. At the same time he bundled all of the company's services in a separate Global Services business unit alongside hardware and software units to make the contribution of services measurable and visible. The new services unit's organizational structure was no longer geared to products but, consistently, to solutions, such as outsourcing or customer

\footnotetext{
In the early 1990s, turnaround research had produced only few substantive results (Pearce and Robbins 1993, p. 614).

10 This decision of Gerstner's led to the book "Who Says Elephants Can't Dance?" in which he looked back on his time as IBM CEO (Gerstner 2003).
}

relationship management, and to industries, such as financial services, in order to bundle and develop the corresponding industry skills. The transformation from a manufacturer of capital-intensive products to a company that in the future would be significantly characterized by laborintensive ("labor-based") services posed a very special challenge - one of which IBM stayed abreast by means of a fundamental reconception of its business processes.

At the same time Gerstner had to usher in a change in corporate culture that for one would help to interpret the company's previously "lived" values correctly and for another would support his strategy. "Until I came to IBM," he later wrote, "I probably would have told you that culture was just one among several important elements in any organization's makeup and success - along with vision, strategy, marketing, financials, and the like. I came to see, in my time at IBM, that culture isn't just one aspect of the game; it is the game. In the end, an organization is nothing more than the collective capacity of its people to create value" (Gerstner 2003, p. 181). He accordingly set IBM three new and simple imperatives:

- Win: Since economic activity takes place in competition, with winners and losers, the market should be the decisive criterion for all business activity. This made it clear that the previous values of excellence and superior service were to be measured by the yardstick of commercial success.

- Execute: Speed and discipline were to overcome the obsessive perfectionism that had led to market opportunities being missed and had left IBM vulnerable to competitors capitalizing on IBM inventions.

- Team: Every employee must act as a part of one IBM - in full accordance with the basic philosophy of the company's integrated solution competence.

During this phase IBM - while still operating at an undiminished level of high technological competence ${ }^{11}$ - developed into the world's largest IT services company: services' share of IBM sales rose continuously from 27 percent in $1993 \mathrm{via}$ 45 percent in 2002 to 55 percent in 2007.

\footnotetext{
11 Since 1993, IBM has registered the most patents in the U.S. year after year, latterly 3,148 patents in 2007 (http://www. networkworld.com/news/2008/011408patent-list.html. Accessed 2008-08-15).
} 


\subsection{The global integration phase}

Starting in the late 1990s, a number of ICT innovations led to the emergence of totally new opportunities and risks, first and foremost the commercial use of the Internet and the establishment of open standards. New forms of cooperation across corporate and national borders became possible and many customers' business models faced fundamental transformations.

Under Sam Palmisano, who took over as CEO in January 2003, IBM continued in principle the course set under Gerstner while integrating three main aspects into the business model:

- Bearing in mind that the swift pace of technological change also poses a challenge for the company's customers, even greater emphasis was put on total solutions for customers that went beyond IT solutions. As an "innovator's innovator," IBM stepped up its commitment to providing customers with integrated assistance to gain a competitive edge in their respective industries ${ }^{12}$. The acquisition of PwCC, with the takeover of a large number of highly qualified consultants with industry-specific experience laid the groundwork for implementation. Global organizational structures were created to make industry-specific know-how available around the world and to provide worldwide support for international customers.

- With the advent of global networks by means of modern ICT, a worldwide integration of processes and value chains within the company became possible, leading to significant economies of scale. Corporate functions were no longer replicated; they were established once only and with global responsibility. For this, Palmisano (2006, p. 131) coined the concept of the globally integrated enterprise.

- As ICT undergoes progressive evolution, the value contributions of individual business segments change as well. IBM consistently focused on premium segments such as integrated management consulting and enlarged them further. Product areas that had become commodities as a result of ICT

\footnotetext{
12 At the same time, technological innovations were still important, such as, in 2005, the cell processor that is used in game consoles or, in May 2008 , Roadrunner, the first petaflop computer.
}

trends were sold off. After the sale of the hard drive division, IBM also sold its PC business to Lenovo in 2005. At the same time it acquired a number of small and midrange software companies, such as Rational in 2003 and Cognos in 2007 , thereby making appropriate additions to the company's solutions portfolio.

This was also directly reflected in IBM's business organization. To make its consulting business both more visible and measurable, the services division was split into two business units, Global Business Services (GBS) and Global Technology Services (GTS). GBS was consistently structured along customer industries and solutions. Central corporate functions such as procurement, supply chain management, and financial management were assigned to a central, worldwide leadership that would be in charge of strategy, processes and systems. Global procurement responsibility, for example, was consolidated in Shenzhen, China, in 2006.

Gerstner had revised the original IBM values that were "lived" dysfunctionally in the early 1990s and changed the company's corporate culture by means of a focus on competitive orientation, speed of implementation, and cooperation towards a "Bias for Action" (Peters and Waterman 1982, pp. 134-136). Palmisano also kick-started a renewal of corporate culture to match it to a now serviceoriented enterprise and an adjusted business model. Rather than centrally revising corporate values, however, IBM invited all of its employees around the world to take part in a joint debate on the company's values. This in turn was only made possible by ICT: an online jam - analogous to informal jazz sessions - gave IBMers an opportunity to share in an open discussion about the desired values (Hemp and Stewart 2004, p. 61). IBM's new values, drawn up in cooperation with all of its employees via the so-called value jam, are now stated to be "dedication to every client's success," "innovation that matters - for our company and for the world," and "trust and personal responsibility in all relationships". They once more take the change of business model and organization into account, incorporating especially IBM's commitment to corporate social responsibility as reflected in the campaign for environment-friendly and low-energy ICT (Green IBM) launched in 2008.

\section{Summary and outlook}

This article has claimed that innovations in ICT call for complementary - in some cases fundamental - adaptations to business model, organization and corporate culture to ensure that a company remains successful even when market conditions have changed. A case in point is IBM's transformation over the past 50 years into a globally integrated, service-oriented enterprise.

Starting with the swifter pace of ICTdriven change and the resulting shorter innovation cycles, we see one of the most urgent tasks for companies in improving their ability to recognize essential changes and to adapt to them in a timely and consistent manner. As business model and organizational transformations and, above all, cultural adjustments, always take their time, it is not surprising that coping with swift change currently appears to be the most serious problem that chief executive officers face. This was impressively demonstrated by the Global CEO Study published at the beginning of 2008 after interviews of over 1,100 CEOs around the world (Fig. 3): "Organizations are bombarded by change, and many are struggling to keep up. Eight out of ten CEOs see significant change ahead, and yet the gap between expected change and the ability to manage it has almost tripled since our last Global CEO Study in 2006" (IBM 2008b, p. 7).

Some of the challenges ahead will be to deal with a fundamental dissolution of the traditional roles and structures of information production and consumption (Web 2.0) that is brought about by ICT. Data and information produced by previous information recipients can be used for innovative business models or for cooperative innovation. At the same time, it will constitute a complex challenge to cope with the flood of user- and increasingly sensor-generated data - at times called a "data tsunami" - in order to extract competitively relevant information. Recent acquisitions of leading business intelligence firms such as Business Objects (by SAP) or Cognos (by IBM) testify to this subject's relevance. Companies must utilize the resulting opportunities. Scientific disciplines such as BISE that integrate technical, economic and human resource aspects in an interdisciplinary manner are called upon to support corresponding transformations and to do so by means of both an appropriate research and educa- 


\section{Abstract \\ Martin Jetter, Gerhard Satzger, Andreas Neus \\ Technological Innovation and Its Impact on Business Model, Organization and Corporate Culture - IBM's Transformation into a Globally Integrated, Service-Oriented Enterprise}

This article investigates the influence of information and communication technology (ICT) on business transformation. First, the general, ICT-driven development lines of globalization and service-orientation are described. Then, an analysis of the IBM Corporation's transformation over the past 50 years into a globally integrated, service-oriented company illustrates that ICT innovations must be dealt with by simultaneous adaptation of business model, organization and corporate culture. For many companies the ability to manage this change becomes increasingly critical.

Keywords: Innovation, Information and communication technology, Business model, Organization, Corporate culture, Transformation, Change management, IBM tion orientation ${ }^{13}$ (Satzger 2008; Maerki and König 2006, pp. 229 ff; Spohrer and Maglio 2008, pp. $241 \mathrm{ff}$ ).

Further acceleration of the pace of change must thereby lead at IBM and at many other companies to further, faster adjustments for which the course must be set here and now. To survive and be successful in a highly dynamic world of which ICT is the hallmark will require a focus on the following points:

- Trends and technical developments must be anticipated better to take an active part in shaping the company's business model. IBM, for example, engages in strategic foresight for itself and its customers by means of the Global Innovation Outlook and the CEO Study (IBM 2008a, IBM 2008b).

- Corporate organization and processes must be kept flexible along the lines of adaptive systems. Service-oriented architectures in the context of business processes, such as IBM has realized in recent years in its IT service factories, may be considered a promising concept in that respect.

- Involving employees early and making them aware of the need for change are critically important for further development of corporate culture in a highly dynamic world. In Germany, for example, IBM launched a number of transformation initiatives in 2007 (n. a. 2008, p. 9), underscoring the personal responsibility of employees for shaping their role in a globalized world economy.

An integrated transformation of business model, organization and corporate culture has always been a critical success factor, as IBM's history has illustrated. With more and even faster ICT innovations to be expected in the future, this ability has become absolutely essential for survival.

\section{References}

Argyris C, Schön D (1978) Organizational learning:
a theory of action perspective. Addison Wesley,
Reading Bainbridge WS, Roco MC (2006) Progressive con-

\footnotetext{
3 As an example, IBM's activities can be cited taking forward research and teaching of service science - internationally by means of the worldwide SSME academic initiative (http://www-304.ibm.com/jct09002c/university/scholars/skills/ssme/, retrieved 2008-08-15) and nationally with the foundation of the Karlsruhe Service Research Institute (http://www. ksri.uni-karlsruhe.de. Accessed 2008-08-15).
}

vergence. In: Bainbridge WS, Roco MC (Hrsg) Managing nano-bio-info-cogno innovations: converging technologies in society. Springer, Dordrecht, pp 18

Baumöl U (2006) Methodenkonstruktion für das Business/IT Alignment. WIRTSCHAFTSINFORMATIK 48(5):314-322

BMBF (2008) Die Hightech-Strategie für Deutschland. http://www.bmbf.de/de/6608.php. Accessed 2008-08-15

Buhl HU, Heinrich B, Henneberger M, Krammer A (2008) Service Science. WIRTSCHAFTSINFORMATIK 50(1):60-65

Burgess J (1993) IBM's \$5 billion loss highest in american corporate history. The Tech 112(66):3, http://www-tech.mit.edu/V112/PDF/N66.pdf. Accessed 2008-08-15

Christensen CM (1997) The innovator's dilemma: when new technologies cause great firms to fail. Harvard Business School Press, Cambridge Christensen EW, Gordon G (1999) An exploration of industry, culture and revenue growth. SAGE Publications

Cabral R (1998) Refining the Cabral-Dahab Science Park management paradigm. International Journal of Technology Management 16(8):813-818

Davis EM, Harding WE, Schwartz RS, Corning J (1964) Solid logic technology: versatile, highperformance microelectronics. IBM Journal of Research and Development 8:102-114

Deutsche Bank Research (2007) Deutschland im Jahr 2020 - Neue Herausforderungen für ein Land auf Expedition. http://www.expeditiondeutschland.de/PROD/DBR_INTERNET_DEPROD/PROD0000000000209595.pdf. Accessed 2008-08-15

Engelhardt WH, Kleinaltenkamp M, Reckenfelderbäumer M (1993) Leistungsbündel als Absatzobjekte. Zeitschrift für betriebswirtschaftliche Forschung 45(5):395-426

Fagerberg J (2004) Innovation: a guide to the literature. In: Fagerberg J, Mowery DC, Nelson RR (eds) The Oxford handbook of innovations. Oxford University Press, pp 1-26

Gartner (2002) IBM/PwCC Bid: Altering the DNA of world's largest IT company. http://www. gartner.com/1_researchanalysis/focus_areas/ special_reports/ibm_pwcc/ibm_pwcc.html. Accessed 2008-08-15

Gartner (2008) Gartner highlights key predictions for IT organisations and users in 2008 and beyond. http://www.gartner.com/it/page. jsp?id=593207. Accessed 2008-08-15

Gerstner LV Jr (2003) Who says elephants can't dance? Leading a great enterprise through dramatic change. Harper Business, New York

Grad B (2002) A personal recollection: IBM's unbundling of software and services. IEEE Annals of the History of Computing 24(1):64-71

Graff HJ (1982) The legacies of literacy. Journal of Communication 32(1):12-26

Hauschildt J, Salomo S (2007) Innovationsmanagement, 4th edn. Vahlen

Hemp P, Stewart TA (2004) Leading change when business is good - an interview with Samuel J. Palmisano. Harvard Business Review 82(12):6070 
IBM (1964) System/360 Announcement. IBM data processing division press release, April 7, 1964. http://www-03.ibm.com/ibm/history/exhibits/ mainframe/mainframe_PR360.html. Accessed 2008-08-15

IBM (2008a) The global innovation outlook. http://domino.research.ibm.com/comm/www_ innovate.nsf/pages/world.gio.html. Accessed 2008-08-15

IBM (2008b) The global CEO study: The enterprise of the future. Armonk

IfM, IBM (2008) Succeeding through service innovation: a service perspective for education, research, business and government. University of Cambridge Institute for Manufacturing, Cambridge

Jørgensen HH, Neus A (2007) Die Change Management Routemap: Empirie trifft Erfahrung. Zeitschrift für Organisationsentwicklung (2):87-89

Kotter JP (1995) Leading change: why transformation efforts fail. Harvard Business Review 73(2):59-67

Maerki HU, König W (2006) Services verändern die Welt. Überwindung jeglichen Silodenkens, auch zwischen Wirtschaft und Wissenschaft! WIRTSCHAFTSINFORMATIK 48(4):229-231

Meffert H (1994) Marktorientierte Führung von Dienstleistungsunternehmen - neuere Entwicklungen in Theorie und Praxis. Die Betriebswirtschaft 54(4):519-541

Meffert H, Bruhn M (2006) Dienstleistungsmarketing. Grundlagen - Konzepte - Methoden, 5th edn. Gabler, Wiesbaden

n. a. (2008) Neues Kleid. prmagazin (5):9-13

Palmisano SJ (2006) The globally integrated enterprise. Foreign Affairs 85(3):127-136
Peters T, Waterman RH Jr (1982) In search of excellence: lessons from america's best-run companies. Harper \& Row

Pearce JA, Robbins K (1993) Toward improved theory and research on business turnaround. Journal of Management 19(3):613-636

Picot A, Reichwald R, Wigand R (2008) Information, organization and management. Springer, Berlin

Pugh EW (1995) Building IBM: shaping an industry and its technology. MIT Press, Cambridge

Pugh EW (2002) Origins of software bundling. IEEE Annals of the History of Computing 24(1):57-58

PwC (2006) The World in 2050 - How big will the major emerging market economies get and how can the OECD compete? http://www.pwc. com/extweb/pwcpublications.nsf/docid/ 56DD37D0C399661D852571410060FF8B/\$file/ world2050emergingeconomies.pdf. Accessed 2008-08-15

Rugman AM, Verbeke A (2004) Regional and global strategies of multinational enterprises. Journal of International Business Studies 35(1):3-18

Satzger G (1999) Kapitalintensive Leistungen im globalen Wettbewerb. Gabler, Wiesbaden

Satzger G (2008) Dienstleistungswissenschaft Anforderungen der Praxis an Dienstleistungsforschung und -lehre. BMBF (ed) Technologie Innovation - Dienstleistung (in press)

Schlett M (1998) Trends in embedded microprocessor design. Computer 31(8):44-49

Schumpeter JA (1983) The theory of economic development. An inquiry into profits, capital, credit, interest, and the business cycle. Reprint,
Transaction Publishers, London

Siegal W, Church AH, Javitch M et al (1996) Understanding the management of change: an overview of managers' perspectives and assumptions in the 1990s. Journal of Organizational Change Management 9(6):54-80

Spohrer J, Kwan SK (2009) Service science, management, engineering, and design (SSMED): an emerging discipline - outline \& references. International Journal of Information Systems in the Service Sector 1(3)

Spohrer J, Maglio PP (2008) The emergence of service science: towards systematic service innovations to accelerate o-creation of value. Production and Operations Management 17(3):238-246

Standard \& Poor's (2007) S\&P releases list of 86 companies in the S\&P 500 since 1957. http:// www2.standardandpoors.com/spf/pdf/ index/030207_86Survivors-Release.pdf. Accessed 2008-08-15

Tomayko JE (1988) Computers in spaceflight: the NASA experience. http://history.nasa.gov/computers/Ch4-3.html. Accessed 2008-08-15

Vargo SL, Lusch RF (2004) Evolving to a new dominant logic for marketing. Journal of Marketing 68(1):1-17

Waterman RH Jr, Peters TJ, Philipps JR (1980) Structure is not organization. Business Horizons 23(3):14-26

Wise TA (1966) I.B.M.'s $\$ 5,000,000,000$ Gamble. Fortune (Sep):118

Wilkins AL, Ouchi WG (1983) Efficient cultures: exploring the relationship between culture and organizational performance. Administrative Science Quarterly 28(3):468-481 